\title{
Faktor-Faktor yang Berhubungan dengan Kejadian Pre Eklampsi pada Kehamilan di RSUD Embung Fatimah Kota Batam Tahun 2012
}

\author{
Dessy Hasmawati
}

\begin{abstract}
Abstrak
Pre eklampsi merupakan komplikasi kehamilan dan persalinan yang ditandai dengan peningkatan tekanan darah, protein urin, dan oedema, kadang disertai komplikasi sampai koma. Keadaan ini akan membawa dampak buruk bagi ibu dan janin bahkan kematian. Penelitian ini bertujuan untuk mengetahui faktor-faktoryang berhubungan antara ibu hamil dengan kejadian pre eklampsi di RSUD Embung Fatimah Kota Batam Tahun 2012 yang meliputi usia ibu, usia kehamilan, paritas, dan penyakit penyerta. Jenis penelitian menggunakan penelitian kuantitatif yang bersifat analitik dengan pendekatan Cross Sectional. Penelitian ini dilakukan pada bulan april 2013. Populasi dalam penelitian ini adalah ibu hamil yang berkunjung di RSUD Embung Patimah Kota Batam, pengambilan sampel dengan total sampling yaitu semua ibu hamil yang pre eklampsi sebanyak 173 orang dan ibu hamil yang tidak mengalami pre eklampsi sebanyak 173 orang. Data yang digunakan adalah sekunder dari register dan rekam medic dengan menggunakan cheklis kemudian dilakukan tabulasi dan dianalisis secara univariat dan bivariat. Hasil penelitian didapatkan dari $50 \%$ ibu hamil dengan pre eklampsi. Ada hubungan usia ibu, paritas, dan penyakit penyerta dengan kejadian pre eklampsi. Tidak ada hubungan usia kehamilan dengan kejadian pre eklampsi. Dari penelitian ini dapat ditarik kesimpulan bahwa ada beberapa faktor yang berhubungan dengan kejadian pre eklampsi oleh karena itu perlukan adanya upaya preventif menegakan kemungkinan pre eklampsi secara dini dengan meningkatkan kualitas dan kuantitas Ante Natal Care serta menghindari terjadinya eklampsi melalui pengorbanan pre eklampsi dengan intensif.
\end{abstract}

Kata kunci: Pre eklampsi, kehamilan, faktor-faktor

\section{Abstract}

Pre eclampsia is a complication of pregnancy and childbirth which is characterized by increased blood pressure, urine protein, and edema, sometimes accompanied by complications to coma. This situation will bring adverse effects to the mother and fetus and even death. This study aims to determine the factors that relate among pregnant women with pre-eclampsia incidence in Batam City Hospital Fatimah Embung 2012 that include maternal age, gestational age, parity, and comorbidities. This type of research uses quantitative analytic research with cross sectional approach. The research was conducted in April 2013. The population is pregnant women who visit the hospital Embung Patimah Batam, sampling a total sampling that all pregnant women with pre-eclampsia as many as 173 people and pregnant women who did not have pre eclampsia as many as 173 people. The data used is from the register and record the secondary medic cheklis then performed using tabulation and analyzed using univariate and bivariate. The results obtained from $50 \%$ of pregnant women with pre-eclampsia. There are corelatation maternal age, parity, and the incidence of comorbidities with pre eclampsia. No association of gestation the incidence of pre eclampsia. From this study it can be concluded that there are several factors associated with the incidence of preeclampsia is therefore necessary preventive measures to uphold the possibility of early pre-eclampsia by increasing the quality and quantity of Antenatal care and avoiding pre eclampsia eclampsia through the sacrifice of the intensive.

Keywords: Pre eclampsia, pregnancy, factors

Affiliasi penulis : Fakultas Kedokteran dan Ilmu Kesehatan Universitas Batam.

Korespondensi : Dessy Hasmawati, email desii.hasmawati@yahoo.com, Telp: 08566609991

\section{PENDAHULUAN}

Pre-eklampsi adalah kondisi khusus dalam kehamilan, ditandai dengan peningkatan tekanan darah (TD) dan proteinuria. Bisa berhubungan dengan kejang (eklampsi) dan gagal organ ganda pada ibu, sementara komplikasi pada janin meliputi restriksi pertumbuhan dan abrupsio plasenta. ${ }^{1}$ Pre-eklampsia adalah peningkatan tekanan darah yang baru timbul setelah usia kehamilan mencapai 20 minggu, disertai dengan penambahan berat badan ibu yang tepat akibat tubuh membengkak dan pada pemeriksaan laboratorium dijumpai protein didalam urine (proteinuri). $^{1,2}$

Pre-eklampsi dan eklampsi merupakan salah satu masalah kesehatan yang sering terjadi pada kehamilan. Pre-eklampsi dan eklampsi dapat menyebabkan retardasi mental, morbiditas dan mortilitas bayi, kelahiran premature, dan kematian ibu. Pre-eklampsi didefinisikan sebagai timbulnya hipertensi disertai dengan proteinuria pada umur kehamilan lebih dari 20 minggu atau segera setelah persalinan. Pre-eklampsia merupakan gangguan multisystem pada kehamilan yang dikarakteristikkan disfungsi endothelial, peningkatan tekanan darah karena vasokontriksi, proteinuria akibat kegagalan 
glomerolus, dan udema akibat peningkatan permeabilitas vaskuler. ${ }^{3}$

Penyakit ini cukup sering dijumpai dan masih merupakan salah satu sebab dari kematian ibu. Di U.S.A. misalnya $1 / 3$ dari kematian ibu disebabkan penyakit ini. Hypertensi dalam kehamilan menjadi juga penyebab yang penting dari kelahiran mati kematian neonatal.

Pre-eklampsia dan eklampsia merupakan kesatuan penyakit, yang termasuk dalam komplikasi sebagai akibat langsung yang disebabkan oleh kehamilan, walaupun belum jelas bagaimana hal itu terjadi. Istilah kesatuan penyakit harus diartikan bahwa kedua peristiwa dasarnya sama dan bahwa eklampsi merupakan peningkatan yang lebih berat dan berbahaya dari pre-eklampsia, dengan tambahan gejala-gejala tertentu. ${ }^{1,4}$

\section{Metode Penelitian}

Merupakan penelitian Cross Sectional dengan desain penelitian secara survey analitik yang bertujuan untuk mengetahui yang terbanyak mengalami Preeklampsi dengan cara menggunakan Rekam Medik. ${ }^{(5)}$

Setelah data diperoleh kemudian diolah dan disajikan dalam bentuk tabel distribusi dan mengetahui hubungan sebab akibat, tetapi untuk mengetahui hubungan diantara variabel independent dan variabel dependent dengan melakukan uji statistic yang dilakukan Chi-Square dengan nilai $\propto=0,05$ diambil sebagai batas kemaknaan. ${ }^{5}$

\section{HASIL PENELITIAN \\ Analisa Univariat}

Hasil analisa univariat pada penelitian ini disajikan dalam bentuk distribusi responden dari setiap variabel dependen (Pre eklampsi) dan variabel independen (usia ibu, usia kehamilan, paritas, dan penyakit penyerta).

Tabel 1. Distribusi Frekuensi Kejadian Pre Eklampsi Pada Ibu Hamil Di RSUD Embung Fatimah Kota Batam Tahun 2012

\begin{tabular}{|c|c|c|}
\hline Kejadian pre eklamsi & Frekuensi & Persentase \\
\hline Ya & 173 & 50 \\
\hline Tidak & 173 & 50 \\
\hline Jumlah & 346 & 100 \\
\hline
\end{tabular}

Dari tabel diatas didapatkan ibu yang mengalami pre eklamsi sebanyak 173 orang (50\%) dan ibu hamil yang tidak mengalami pre eklampsi sebanyak 173 orang (50\%).

Tabel 2. Distribusi Frekuensi Kejadian Pre Eklampsi Pada Ibu Hamil Menurut Usia Ibu Di RSUD Embung Fatimah Kota Batam Tahun 2012

\begin{tabular}{|l|l|l|}
\hline Usia ibu & Frekuensi & Persentase \\
\hline $20-35$ tahun & 261 & 75,4 \\
\hline$<20$ dan $>30$ tahun & 85 & 24,6 \\
\hline Jumlah & 346 & 100 \\
\hline
\end{tabular}

Dari tabel diatas kejadian pre eklampsi pada ibu hamil yang tertinggi terdapat pada usia ibu 20-35 tahun sebanyak 261 orang $(75,4 \%)$, dan terendah pada usia $<20$ dan $>35$ tahun sebanyak 85 orang $(24,6 \%)$.

Tabel 3. Distribusi Frekuensi Kejadian Pre Eklampsi Pada lbu Hamil Menurut Usia Kehamilan Di RSUD Embung Fatimah Kota Batam Tahun 2012

\begin{tabular}{|l|l|l|}
\hline Usia kehamilan & Frekuensi & Persentase \\
\hline Trimester II & 7 & 2,0 \\
\hline Trimester III & 339 & 98,0 \\
\hline Jumlah & 346 & 100 \\
\hline
\end{tabular}

Dari tabel diatas kejadian pre eklampsi pada ibu hamil menurut usia kehamilan terbanyak terdapat pada Trimester III sebanyak $339(98,0 \%)$ dan terendah pada usia kehamilan Trimester II sebanyak 7 (2,0\%).

Tabel 4. Distribusi Frekuensi Kejadian Pre Eklampsi Pada Ibu Hamil Menurut Paritas Di RSUD Embung Fatimah Kota Batam Tahun 2012

\begin{tabular}{|c|c|c|}
\hline Paritas & Frekuensi & Persentase \\
\hline Multigravida & 223 & 64,5 \\
\hline Primigravida & 123 & 35,5 \\
\hline Jumlah & 346 & 100 \\
\hline
\end{tabular}

Dari tabel diatas kejadian pre eklampsi pada ibu hamil menurut paritas terbanyak terdapat pada Multigravida sebanyak 223 orang (64,5\%) dan terendah terdapat pada Primigravida sebanyak 123 orang $(35,5 \%)$.

Tabel 5. Distribusi Frekuensi Kejadian Pre Eklampsi Pada Ibu Hamil Menurut Penyakit Penyerta Di RSUD Embung Fatimah Kota Batam Tahun 2012

\begin{tabular}{|c|c|c|}
\hline $\begin{array}{c}\text { Penyakit } \\
\text { penyerta }\end{array}$ & Frekuensi & Persentase \\
\hline Tidak & 325 & 93,9 \\
\hline Ya & 21 & 6,1 \\
\hline Jumlah & 346 & 100 \\
\hline
\end{tabular}

Dari tabel diatas kejadian pre eklampsi pada ibu hamil menurut penyakit penyerta terbanyak tidak mempunyai penyakit penyerta sebanyak 325 orang $(93,9 \%)$ dan terendah pada yang mempunyai penyakit penyerta sebanyak 21 orang $(6,1 \%)$.

\section{Analisa Bivariat}

Analisis bivariat merupakan uji statistik untuk mengetahui adanya hubungan antara variabel dependen (pre eklampsi) dengan variabel independen (usia ibu, usia kehamilan, paritas, penyakit penyerta). Analisis bivariat dengan mengunakan metode statistic chi square pada derajat kepercayaan/Cl $95 \%$ $(\alpha=0.05)$. 
Tabel 6. Hubungan Antara Usia Ibu Dengan Kejadian Pre Eklampsi Di RSUD Embung Fatimah Kota Batam Tahun 2012

\begin{tabular}{|c|c|c|c|c|c|c|c|c|}
\hline \multirow[t]{3}{*}{ Usia Ibu } & \multicolumn{4}{|c|}{ Kejadian pre eklampsi } & \multicolumn{2}{|c|}{ Total } & \multirow{3}{*}{$\begin{array}{c}P \\
\text { value }\end{array}$} & \multirow{3}{*}{ OR } \\
\hline & \multicolumn{2}{|c|}{ Tidak } & \multicolumn{2}{|c|}{ Ya } & & & & \\
\hline & $\mathrm{n}$ & $\%$ & $\mathrm{n}$ & $\%$ & & & & \\
\hline $\begin{array}{l}20-35 \\
\text { tahun }\end{array}$ & 138 & 52,9 & 261 & 100 & 261 & 100 & & \\
\hline $\begin{array}{c}<20 \text { dan } \\
>35 \text { tahun }\end{array}$ & 35 & 41,2 & 85 & 100 & 85 & 100 & 0,080 & $\begin{array}{c}1,60 \\
3\end{array}$ \\
\hline Jumlah & 173 & 50,0 & 346 & 100 & 346 & 100 & & \\
\hline
\end{tabular}

Hasil analisis hubungan usia ibu dengan kejadian pre eklampsi diperoleh bahwa dari 261 responden pada usia 20-35 tahun mengalami kejadian pre eklampsi 123 orang $(47,1 \%)$ dan dari 85 responden pada usia $<20$ tahun dan $>35$ tahun sebagian besar mengalami pre eklampsi yaitu 50 orang (58,8\%). Hasil uji statistik ( chi-square ) diperoleh nilai $P-$ Value $=0,080$, jika dibandingkan dengan alpha $(\alpha) 0,05$ bearti $P<\alpha$, artinya Ho ditolak menunjukan ada hubungan yang signifikan antara usia ibu dengan kejadian pre eklampsi.

Tabel 7. Hubungan Antara Usia Kehamilan Dengan Kejadian Pre Eklampsi Di RSUD Embung Fatimah Kota Batam Tahun 2012

\begin{tabular}{|c|c|c|c|c|c|c|c|c|}
\hline \multirow{3}{*}{$\begin{array}{c}\text { Usia } \\
\text { kehamila } \\
\text { n }\end{array}$} & \multicolumn{4}{|c|}{ Kejadian pre eklampsi } & \multicolumn{2}{|c|}{ Total } & \multirow{3}{*}{$\begin{array}{c}P \\
\text { value }\end{array}$} & \multirow[t]{2}{*}{ OR } \\
\hline & \multicolumn{2}{|c|}{ Tidak } & \multicolumn{2}{|c|}{ Ya } & \multirow{2}{*}{$\mathrm{n}$} & \multirow{2}{*}{$\%$} & & \\
\hline & $\mathrm{n}$ & $\%$ & $\mathrm{n}$ & $\%$ & & & & \\
\hline $\begin{array}{c}\text { Trimester } \\
\text { II }\end{array}$ & 6 & 85,7 & 1 & 14,3 & 7 & 100 & & \\
\hline $\begin{array}{c}\text { Trimester } \\
\text { III }\end{array}$ & 167 & 49,3 & 339 & 100 & 339 & 100 & 0,121 & 6,180 \\
\hline Jumlah & 173 & 50,0 & 346 & 100 & 346 & 100 & & \\
\hline
\end{tabular}

Hasil analisis hubungan antara usia kehamilan dengan kejadian pre eklampsi diperoleh bahwa dari 7 responden pada trimester II mengalami kejadian pre eklampsi 1 orang (14,3\%) dan dari 339 responden pada trimester III yang mengalami pre eklampsi sebanyak 172 orang $(50,7 \%)$. Hasil uji statistik ( chi-square ) diperoleh nilai $P$ - value $=0,121$, jika dibandingkan dengan alpha (a) 0,05 berarti $P>\alpha$, artinya Ho diterima menunjukan tidak ada hubungan yang signifikan antara usia kehamilan ibu dengan kejadian pre eklampsi.

Tabel 8. Hubungan Antara Paritas Dengan Kejadian Pre Eklampsi Di RSUD Embung Fatimah Kota Batam Tahun 2012

\begin{tabular}{|c|c|c|c|c|c|c|c|c|}
\hline \multirow{3}{*}{ Paritas } & \multicolumn{4}{|c|}{ Kejadian pre eklampsi } & \multicolumn{2}{|c|}{ Total } & \multirow{2}{*}{$\begin{array}{c}\mathbf{P} \\
\text { value }\end{array}$} & \multirow{2}{*}{ OR } \\
\hline & \multicolumn{2}{|c|}{ Tidak } & \multicolumn{2}{|c|}{ Ya } & \multirow{2}{*}{$\mathrm{n}$} & \multirow{2}{*}{$\%$} & & \\
\hline & $\mathrm{n}$ & $\%$ & $\mathrm{n}$ & $\%$ & & & & \\
\hline $\begin{array}{c}\text { Multigrav } \\
\text { ida }\end{array}$ & 6 & 85,7 & 1 & 14,3 & 223 & 100 & & \\
\hline $\begin{array}{c}\text { Primigrav } \\
\text { ida }\end{array}$ & 167 & 49,3 & 339 & 100 & 123 & 100 & 0,000 & 2,464 \\
\hline
\end{tabular}

\begin{tabular}{|l|l|l|l|l|l|l|l|l|}
\hline Jumlah & 173 & 50,0 & 346 & 100 & 346 & 100 & & \\
\hline
\end{tabular}

Hasil analisis hubungan antara paritas dengan kejadian pre eklampsi diperoleh bahwa dari 223 responden pada multigravida mengalami kejadian 94 orang $(42,2 \%)$ dan dari 123 responden pada primigravida sebagian besar mengalami pre eklampsi sebanyak 79 orang $(64,2 \%)$. Hasil uji statistik ( chisquare ) diperoleh nilai $P-$ value $=0,000$, jika dibandingkan dengan alpha $(\alpha) 0,05$ berarti $P<\alpha$, artinya Ho ditolak menunjukkan ada hubungan yang signifikan antara paritas dengan kejadian pre eklampsi.

Tabel 9. Hubungan Antara Penyakit Penyerta Dengan Kejadian Pre Eklampsi Di RSUD Embung Fatimah Kota Batam Tahun 2012

\begin{tabular}{|c|c|c|c|c|c|c|c|c|}
\hline \multirow{3}{*}{ Paritas } & \multicolumn{4}{|c|}{ Kejadian pre eklampsi } & \multicolumn{2}{|c|}{ Total } & \multirow{3}{*}{$\begin{array}{c}P \\
\text { value }\end{array}$} & \multirow[t]{3}{*}{ OR } \\
\hline & \multicolumn{2}{|c|}{ Tidak } & \multicolumn{2}{|c|}{ Ya } & \multirow{2}{*}{$\mathrm{n}$} & \multirow{2}{*}{$\%$} & & \\
\hline & $\mathrm{n}$ & $\%$ & $\mathrm{n}$ & $\%$ & & & & \\
\hline $\begin{array}{c}\text { Multigrav } \\
\text { ida }\end{array}$ & 129 & 57,8 & 94 & 42,2 & 223 & 100 & & \\
\hline $\begin{array}{c}\text { Primigrav } \\
\text { ida }\end{array}$ & 44 & 35,8 & 79 & 64,4 & 123 & 100 & 0,000 & 2,464 \\
\hline Jumlah & 173 & 50,0 & 173 & 50,0 & 346 & 100 & & \\
\hline
\end{tabular}

Hasil analisis hubungan antara penyakit penyerta dengan kejdian pre eklampsi diperoleh bahwa dari 325 responden tanpa penyakit penyerta mengalami kejadian 157 orang (48,3\%) dan dari 21 responden dengan penyakit penyerta sebagian besar mengalami pre eklampsi sebanyak 16 orang $(76,2 \%)$. Hasil uji statistik ( chi-square ) diperoleh nilai $P$ - value $=0,022$, jika dibandingkan dengan alpha $(\alpha) \quad 0,05$ berarti $P<\alpha$, artinya Ho di ditolak menunjukkan ada hubungan yang sigbnifikan antara paritas dengan kejadian pre eklampsi.

\section{PEMBAHASAN}

\section{Analisa Univariat}

Hasil penelitian di RSUD Embung Fatimah Kota Batam didapatkan ibu yang mengalami Pre Eklampsi sebanyak 173 orang (50\%) dan ibu hamil yang tidak mengalami Pre Eklampsi sebanyak 173 orang (50\%). Diperkirakan hipertensi permanen, terjadi pada $30 \%$ sampai $50 \%$ pasien dengan preeklampsi berat dan eklampsi dan kemungkinan $40 \%$ sampai $50 \%$ pasien dengan preeklampsi berat atau eklampsi memiliki kemungkinan kejadian yang sama pada kehamilan berikutnya. Hal ini tidak sejalan dengan teori di atas dikarenakan pengambilan sampel penelitian ini adalah 1:1 yaitu ibu hamil yang mengalami Pre eklampsi sebanyak 173 orang dan ibu yang tidak mengalami Pre eklampsi sebanyak 173 orang.

Dari hasil penelitian ini didapatkan kejadian Pre Eklampsi pada ibu hamil yang tertinggi terdapat pada usia ibu 20-35 tahun sebanyak 261 orang (75,4\%), dan terendah pada usia $<20$ dan $>35$ tahun sebanyak 85 orang $(24,6 \%)$. Usia sangat menentukan status kesehatan ibu. Kejadian Pre eklampsi eklampsi berdasarkan umur banyak ditemukan pada kelompok usia ibu yang ekstrim yaitu kurang dari 20 tahun dan lebih dari 35 tahun. Pada ibu hamil usia 
kurang dari 20 tahun belum matang dalam menghadapi kehamilan baik pada organ reproduksi maupun mental. Pada usia ibu lebih dari 35 tahun, dalam tubuh telah terjadi perubahan-perubahan akibat penuaan organ-organ. Dengan begitu, kemungkinan untuk mendapatkan penyakit-penyakit dalam masa kehamilan yang berhubungan dengan umur akan meningkat, seperti penyakit darah tinggi, keracunan kehamilan (pre eklampsi/eklampsi), diabetes, penyakit jantung dan pembuluh darah. Tetapi kejadian pre eklampsi tidak menutup kemungkinan terjadi pada usia 20-35 tahun, seperti pada hasil penelitian ini yang jumlah terbanyak yang mengalami pre eklampsi pada usia 20-35 tahun karena penyebab pre eklampsi belum pasti, banyak faktor yang mempengaruhinya.

Dalam penelitian ini usia kehamilan dibag yaitu trimester II dan trimester III dikarenakan menurut Prawirohardjo, tahun 2005 pre eklampsi terjadi pada kehamilan 20 minggu dan kejadiannya meningkat seiring tuanya usia kehamilan dan pada umumnya kejadiannya lebih banyak pada trimester III. Dan hasil penelitian ini kejadian Pre eklampsi pada ibu hamill menurut usia kehamilan terbanyak terdapat pada trimester III sebanyak 339 orang $(98,0 \%)$ dan terendah pada usia kehamilan trimester II sebanyak 7 orang $(2,0 \%)$.

Dalam penelitian ini secara distribusi frekuensi Pre eklampsi pada ibu hamil menurut paritas terbanyak terdapat pada multigravida sebanyak 223 orang $(64,5 \%)$ dan terendah pada primigravida sebanyak 123 orang (35,5\%).

Dalam penelitian ini yang termasuk dalam penyakit penyerta yaitu hipertensi dan gamely yang merupakan faktor predisposisi terjadinya pre eklampsi. Hasil penelitian ini didapatkan kejadian pre eklampsi pada ibu hamil menurut penyakit penyerta terbanyak 325 orang $(93,9 \%)$ tidak mengalami penyakit penyerta dan terendah pada yang mempunyai penyakit penyerta sebanyak 21 orang $(6,1 \%)$.

\section{Analisa Bivariat}

Hasil uji statistik berdasarkan usia ibu menunjukkan responden yang berusia $<20$ dan $>35$ tahun adalah terbanyak (58,8\%) mengalami Pre eklampsi, dibandingkan dengan yang berusia 20-35 tahun $(47,1 \%)$, menunjukkan perbedaan yang signifikan sehingga ada hubungan yang bermakna antara usia ibu dengan kejadian pre eklampsi pada ibu hamil dengan nilai $P$ value sebesar 0,080 . Dengan demikian dapat disimpulkan secara statistic dengan derajat kepercayaan $25 \%$, diyakini terdapat yang siginifikan antara usia ibu dengan Pre eklampsi pada ibu hamil, dengan nilai OR 1,603 yang berarti usia ibu dibawah $<20$ dan $>35$ tahun berpeluang 1 kali lebih besar terhadap usia ibu 20-35 tahun dibandingkan dengan usia ibu dibawah $<20$ dan $>35$ tahun. Hasil penelitian menyebutkan bahwa dari 85 orang ibu usia $<20$ dan $>35$ tahun sebanyak 50 orang $(58,8 \%)$ mengalami pre eklampsi, sedangkan pada usia 20-35 tahun dari 261 orang ibu hamil yang mengalami pre eklampsi sebanyak 123 orang $(47,1 \%)$. Pada kelompok control diperoleh ibu hamil pada usia 20-35 tahun tidak mengalami pre eklampsi sebanyak 138 orang $(52,9 \%)$, sedangkan pada usia $<20$ dan $>35$ tahun sebanyak 35 orang $(41,2 \%)$ tidak mengalami pre eklampsi. Hal ini dapat disimpulkan bahwa kehamilan usia ibu $<20$ dan $>35$ tahun sangat memungkinkan untuk terjadi pre eklampsi pada kehamilan bila dibandingkan pada kehamilan usia ibu
20-35 tahun. Pada umumnya usia <20 tahun rahim dan tulang panggul serta sirkulasi darah belum berkembang secara sempurna, sehingga kemungkinan akan mengalami kesulitan persalinan dan mengalami pre eklampsi lebih besar. Sesudah umur 35 tahun, kesehatan, penuaan organ dan keadaan rahim ibu sudah menurun, sehingga akan terjadi persalinan lama, perdarahan, pre eklampsi dan resiko kecacatan bayi yang dikandungnya. Hubungan peningkatan usia terhadap pre eklampsi dan eklampsi adalah sama dan penigkatan lagi pada wanita hamil yang berusia diatas 35 tahun. Usia 20-35 tahun adalah periode paling aman untuk melahirkan, akan tetapi di Negara berkembang sekitar $10-20 \%$ bayi dilahirkan dari ibu remaja. Padahal dari suatu penelitian ditemukan bahwa dua tahun setelah menstruasi yang pertama, seorang anak wanita masih mungkin mencapai pertumbuhan panggul antara $2-7 \%$ dan tinggi badan $1 \%$. Kejadian pre eklampsi-eklampsi berdasarkan usia banyak ditemukan pada kelompok usia ibu yang ekstrim yaitu kurang dari 20 tahun dan lebih dari 35 tahun (Sarwono, 2009). Dengan tingginya kemungkinan terjadinya Pre eklampsi pada ibu hamil diusia $<20$ tahun dan >35 tahun maka anjuran untuk hamil diusia yang paling aman sangat diperlukan yaitu pada usia 20-35 tahun. Tetapi usia 20-35 tahun tetap harus dilakukan deteksi dini kejadian Pre eklampsi karena penyebab pre eklampsi banyak faktor yang mempengaruhi (multifactor) jadi kejadian Pre eklampsi bisa saja terjadi ada usia ibu 20-35 tahun tetapi peluangnya lebih kecil dibandingkan dengan usia $<20$ tahun dan $>35$ tahun.

Berdasarkan uji statistik tidak terdapat hubungan yang bermakna antara usia kehamilan ibu dengan kejadian pada ibu hamil, dimana tidak ada perbedaan yang sifnifikan antara ibu pada trimester II $(14,3 \%)$ dan trimester III $(50,7 \%)$, dengan nilai $P$ value sebesar 0,121 . Dengan demikian dapat disimpulkan secara statistic dengan derajat kepercayaan 95\%, diyakini terdapat yang tidak signifikan antara usia kehamilan dengan pre eklampsi pada ibu hamil, dengan nilai OR 6,180 yang berarti trimester III berpeluang 6 kali lebih besar terhadap trimester II dibandingkan dengan trimester III. Dari hasil penelitian ini didapatkan bahwa kasus pre eklampsi diderita oleh ibu hamil trimester II sebanyak 1 orang $(14,3 \%)$ dan yang tidak pre eklampsi sebanyak 6 orang $(85,7 \%)$. Sedang pada trimester Illyang mengalami pre eklampsi sebanyak 172 orang $(50,7 \%)$ dan yang tidak mengalami pre eklampsi sebanyak 167 orang $(49,3 \%)$. Hal ini dapat disimpulkan bahwa kejadian pre eklampsi pada kehamilan trimester II bisa saja terjadi dan mempunyai peluang yang sama dengan kehamilan pada trimester III. Oleh karena itu deteksi dini sangat penting pada ibu hamil dengan pelaksanaan antenatal yang teratur dan berkualitas. Deteksi dini pre eklampsi harus dilaksanakan setelah ibu memasuki trimester II. kejadian pre eklampsi meningkat seiring dengan bertambahnya usia kehamilan. Penyakit ini umumnya terjadi pada trimester III kehamilan, tetapi dapat terjadi sebelumnya. Pre eklampsi adalah suatu sindroma spesifik kehamilan dengan menurutnya perfusi organ yang berakibat terjadinya vasospasme pembuluh darah dan aktivasi endotel yang ditandai dengan tingginya tekanan darah dan kelebihan kadar protein dalam urin setelah kehamilan berusia 20 minggu. Dalam hal ini penelitian ini sejalan dengan teori berarti pre eklampsi dapat juga terjadi pada trimester II kehamilan. 
Hasil penelitian ada perbedaan yang signifikan pada ibu primigravida lebih besar $64,2 \%$ yang mengalami pre eklampsi dibandingkan dengan ibu multigravida cendrung lebih rendah 42,2\%. Menunjukkan ada hubungan yang bermakna antara dengan paritas dengan kejadian pre eklampsi pada ibu hamil dengan nilai $P$ value 0,000 . Dengan demikian dapat disimpulkan secara statistic dengan derajat kepercayaan $30 \%$, diyakini terdapat yang signifikan antara paritas dengan pre eklampsi pada ibu hamil, dengan nilai OR 2,464 yang berarti multigravida berpeluang 2 kali lebih besar terhadap primigravida dibandingkan dengan primigravida. Berdasarkan hasil penelitian ini paritas sangat menentukan untuk terjadinya pre eklampsi pada ibu hamil. Pada primigravida mempunyai peluang yang lebih besar untuk terjadi pre eklampsi bila dibnadingkan dengan multigravida. Hasil penelitian ini didapatkan dari 223 ibu multigravida $57,8 \%$ tidak mengalami pre eklampsi dan $42,2 \%$ mengalami pre eklampsi, sedangkan pada primigravida dari 123 responden yang mengalami pre eklampsi $64,2 \%$ dan $35,8 \%$ tidak mengalami pre eklampsi. Dalam hal ini kehamilan primigravida diperlikan pengawasan yang lebih tetapi tidak mengabaikan pada kehamilan multigravida karena pre eklampsi juga dapat terjadi multigravida. Pendidikan kesehatan atau informasi tentang kehamilan dan tanda bahaya sangat diutamakan dalam memberikan pelayanan antenatal terutama pada ibu primigravida, pada ibu primigravida muda pengawasan kehamilan sangat diperlukan Karena selain secara fisik dan psikis belum siap untuk hamil ibu primigravida muda mempunyai beberapa masalah yang umum pada remaja. Primigravida tua juga harus diperhatikan karena kondisi kesehatannya sudah mulai menurun sehingga akan terjadi gangguan pembuluh darah. Pembatasan paritas juga sangat diperlukan untuk mengurangi kejadian pre eklampsi. Ibu dengan paritas tinggi biasanya kondisi kesehatannya menurun apalagi disertai dengan jarak kelahiran yang terlalu dekat dan usia ibu >35 tahun dan kehamilan yang berulangulang akan mempengaruhi pembuluh darah yang akan mempengaruhi aliran darah ke uterus pada masa kehamilan.

Hasil penelitisn menunjukan responden yang mempunyai penyakit penyerta $76,2 \%$ mengalami pre eklampsi lebih tinggi dari responden yang tidak mempunyai penyakit penyerta $23,8 \%$. Menunjukkan ada hubungan yang bermakna antara paritas dengan kejadian pre eklampsi pada ibu hamil dengan nilai $\mathrm{P}$ value 0,022 . Dengan demikian dapat disimpulkan secara statistic dengan derajat kepercayaan 90\%, diyakini terdapat yang signifikan antara penyakit penyerta dengan pre eklampsi pada hamil, dengan nilai OR 3,424 yang berarti yang mempunyai penyakit penyerta berpeluang 3 kali lebih besar terhadap yang tidak mempunyai penyakit penyerta dibandingkan dengan yang mempunyai penyakit penyerta. Hasil penelitian ini menunjukan bahwa ibu hamil dengan penyakit penyerta seperti hipertensi mempunyai peluang yang lebih besar untuk terjadi pre eklampsi bila dibandingkan dengan ibu yang tidak mempunyai penyakit penyerta. Dimana riwayat penyakit yang paling dominan dialami pada responden dalam penelitian ini adalh hipertensi.

\section{KESIMPULAN}

Angka kejadian pre eklamsi pada ibu hamil sebanyak 50\%. Distribusi frekuensi kejadian pre eklamsi mayoritas pada usia 20-35 tahun sebanyak $75,4 \%$. Distribusi frekuensi kejadian pre eklamsi mayoritas pada trimester III sebanyak 98,0\%. Distribusi frekuensi kejadian pre eklamsi terbanyak pada multigravida sebanyak 64,5\%. Distribusi frekuensi kejadian pre eklamsi mayoritas tidak disertai penyakit penyerta sebanyak $32,5 \%$. Ada hubungan yang signifikan antara usia ibu dengan kejadian pre eklamsi diperoleh nilai $P$ - value $=0,080$. Tidak ada hubungan antara usia kehamilan dengan kejadian pre eklamsi diperoleh nilai $P-$ value $=0,121$. Ada hubungan yang signifikan antara paritas dengan kejadian pre eklamsi diperoleh nilai $P$ - value $=0,000$. Ada hubungan antara penyakit penyerta dengan kejadian pre eklamsi diperoleh nilai $P$ - value $=0,022$

\section{DAFTAR PUSTAKA}

1. Arikunto, Suharsimi. 2006. Prosedur Suatu Pendekatan Praktek, Jakarta: Rineka Cipta

2. Chapman, Vicky. 2006. Asuhan Kebidanan Persalinan dan kelahiran, Jakarta: EGC.

3. Fauziyah, Yulia. 2012. Obstetri Patologi Untuk Mahasiswa Kebidanan dan Keperawatan, Yogyakarta: Nuha Medika.

4. Hidayat, A. Aziz Alimul. 2011. Metode Penelitian Kebidanan Teknis Analisa data, Jakarta: Salemba Medika.

5. Machfoedz, Ircham. 2008. Metodologi Penelitian Kuantitatif dan Kualitatif Bidang Kesehatan, keperawatan, Kebidanan, Kedokteran, Yogyakarta : Fitramaya.

6. Nugroho, Taufan. 2012. Obstetri dan Ginekologi Untuk Kebidanan dan Keperawatan, Yogyakarta : Nuha Medika

7. Nugroho, Taufan. 2012. Patologi Kebidanan, Yogyakarta : Nuha Medika.

8. Notoatmodjo, Soekijo. 2010. Metodologi Penelitian Kesehatan, Jakarta: Rineka Cipta

9. Notoatmodjo, Soekijo. 2005. Metodologi Penelitian Kesehatan, Jakarta : Rineka Cipta

10. Prawirohardjo, Sarwono. 2006. IImu Kebidanan, Jakarta : Bina Pustaka

11. Prawirohardjo, Sarwono. 2009. IImu Kebidanan, Jakarta : Bina Pustaka.

12. Rukiyah, Ai Yeyeh S.Si.T, lia Yulianti, Am.Keb, MKM. 2010. Asuhan Neonatus, Bayi dan Anak Balita, Jakarta : CV. Trans Info Media.

13. Rumengan, Jemmy. 2008. Metodelogi Penelitian Kesehatan, Bandung : Citapustaka Media Perintis.

14. Tresnawati, Frisca. 2012. Asuhan Kebidanan Panduan Lengkap Menjadi Bidan Profesional, Jakarta : Prestasi Pustakaraya. 